\title{
Performance enhancement of solar powered floating photovoltaic system using arduino approach
}

\author{
Nur Amirah Abdul Jamil ${ }^{1}$, Siti Amely Jumaat ${ }^{2}$, Suriana Salimin $^{3}$, Mohd Noor Abdullah ${ }^{4}$, \\ Ahmad Fateh Mohamad Nor ${ }^{5}$ \\ ${ }^{1}$ Departement of Electrical Engineering, Faculty of Electrical and Electronics Engineering, \\ Universiti Tun Hussein Onn Malaysia, Malaysia \\ 2,3,4,5 Green and Sustainable Energy Focus Group (GSEnergy), Faculty of Electrical and Electronics Engineering, \\ Universiti Tun Hussein Onn Malaysia, Malaysia
}

\begin{tabular}{l} 
Article Info \\
\hline Article history: \\
Received Oct 22, 2019 \\
Revised Dec 21, 2019 \\
Accepted Jan 30, 2020 \\
\hline
\end{tabular}

Keywords:

Arduino

Floating Photovotaic

Power enhancement

PV

\begin{abstract}
This paper presents Performance Enhancement of Solar Powered Floating Photovoltaic System using Arduino Approach. In the project, an Arduino nano as a main controller of the system. The objective of this project to monitor performance of the voltage, current and power output respectively. Furthermore, the prototype of the research is testing in two conditions: on water surface and on a land area. Based on the results, the power of the photovoltaic on the water surface is increased compared on the land area. The conclusion for this project is it can generate electricity using floating photovoltaic and the same time to monitor output of the system.
\end{abstract}

This is an open access article under the CC BY-SA license.

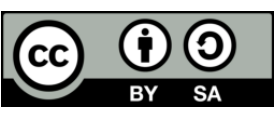

Corresponding Author:

Siti Amely Jumaat,

Green and Sustainable Energy Focus Group,

Faculty of Electrical and Electronics Engineering,

Universiti Tun Hussein Onn Malaysia

86400 Parit Raja, Batu Pahat, Johor, Malaysia

Email: sitiamely1979@gmail.com

\section{INTRODUCTION}

A solar technology is not a recent development, it stated on the mid 1800's to the industrial revolution when solar plants were developed a heat water is produced a steam to drive machinery [1]. Thorough, renewable energy technologies need the use of large land spaces in order to produce electricity. Definitely, for photovoltaic (PV) systems, great surface areas are required because of low density power of solar energy. A solar energy is energy formed by sun created over a thermonuclear process and this process creates heat and electromagnetic radiations. These electromagnetic radiations have the energy that reaches the earth. A floating PV refers to the installation of photovoltaic on water surfaces, such as lakes, pond, reservoirs, hydroelectric dams and other often under-operated water surface, with PV panels usually attached upon a pontoon-based floating structure. A floating PV has massive market potential. It is estimated to become the third major sector for PV development after ground attached and rooftop PV. Nowadays, the use of photovoltaic system has expanded quickly the last period and today's market contains several different solar exploitations, where floating PV is some of them [2]. Earlier studies have exposed how floating PV system rise the photovoltaic panel productivity and at the same time decrease the water evaporation. A floating photovoltaic energy system offer numerous advantages over systems mounted on land. Firstly, 
a floating photovoltaic are installed on water surface, the land can be preserved and used for other purpose. Secondly, a floating photovoltaic deliver energy generation efficiency since the ambient temperature of water is comparatively low. Finally, evaporation from the water surface could be reduced when a floating photovoltaic system is installed in a lake or reservoir.

A solar photovoltaic not only protects productive land, but also protects valuable fresh water for generations to come. The simulated outcomes showed how the situations considering floating photovoltaic system created a higher reliability than the situations considering ground-mounted photovoltaic system [3]. A module cleaning has a major effect on the overall performance of utility-scale, ground-mounted PV projects. It requires adequate good quality water in the vicinity of the project. A floating PV panels are installed in low dust locations and can always use sprinklers to clean themselves, the systems have the potential to reduce evaporation up to 70 per cent [4]. The usual ambient temperature on water surface is lower than that on land due to the water-cooling effect, which enhances the presentation of floating PV modules. The project can be commissioned faster than utility-scale project of similar capacity since it does not involve movement of any heavy equipment at site. A floating photovoltaic panel technology has been achieved traction as a satisfactory and cost-effective alternative to the land-based PV systems. A revolution to renewable energy, the floating solar system market attitudes as one of the top potential equipment in the go green scene. As more and more states gradually be aware of the effective consumption of water bodies over the land space, the floating solar panel market is predictable to gain a further edge across numerous geographies. In paper [1] discusses the floating photovoltaic systems stand as development of technology that suitable for large energy power plants especially for non-usage water pond or lake.

The projects are collaborating with a Compressed Air Energy Storage (CAES) system into floating photovoltaic system using the pipes, that use as modular raft structure to added buoyancy. In paper [2] are discusses on thirteen floating photovoltaic power plants in Korea that have been installed from 2009 to 2014 . The floating photovoltaic system has increased interest in Korea country as one of the best renewable energy alternatives. Next, in paper [3], a photovoltaic generating plant will require a great land area compared to other generating methods. A small panels of photovoltaic system development will only involve floatation in a small depth of water, it may be installed in a pond, lakes or wherever needed. The increasing in generating capacity could be considerable. A platform for floating must be made of a hollow sections' material for an effective buoyancy to self-weight ratio. The platform material will be designed to any desired form and can be attached together by chemical bonding. In paper [4] shows a study about canal top solar system with plane reflectors for the attention of the energy from sunlight has been done. The key parameters that affect the floating photovoltaic performance is amount of solar radiation, temperature and shading area which is adjusted. Additional cooling system is not compulsory for this floating PV system due to the occurrence of water inside canal which will condenses to provide a cooling effect to the system.

The water evaporation loss may reduce and an additional of a solar radiation will get on the solar panel by the consumption of reflector. This paper [5] discusses a good potential for Floating Solar PV (FSPV) are installed on reservoirs. A floating solar photovoltaic is used with pumped hydro energy system storage and hydroelectric in the existing reservoirs. This research is estimate and analysis of potential in India for the model in the present and future. In paper [6], it states that in order to decrease the reservoir shading area on the water surface, a greater fitted power per panel was selected. It was equal to $103.5 \mathrm{kWp}$, equivalent to about 300 panels are fitted on 46 structure of floating panel in area about 1.5. In paper [7] discussed a floating solar photovoltaic system at Kota Barrage and Kishore Sagar lake Kota in Rajasthan. This paper concentrate on floating photovoltaic technology, describing on types of floating photovoltaic plant along with research that being carried out on some floating solar plant.

The floating photovoltaic plant can be set up on a pond, lake, reservoir, or on any other water surface. $1 \mathrm{MW}$ floating plant in Kota barrage can made up to 18,38,519 $\mathrm{kWh}$ electrical energy per year and might save 37 million liters of water and about 1,714 tons of emissions can be reduced annually. For Kishore Sagar lake Floating plant, 1MW floating pv plant mightharvest 18,58,959 kWh energy annually and can save up water to 37 million liters and reduce about 1,733 tons of emissions yearly. The objectives of this project to design of floating photovoltaic to generate electricity, to monitor the voltage and current performance of floating solar system and to evaluate the effectiveness of system at on water surface.

\section{RESEARCH METHOD}

The main components of this project are the photovoltaic panel, the charge controller circuit, a LCD display and a rechargeable battery as shown in Figure 1. Next, the Figure 2 shows the block diagram of a solar charger controller to the load. A photovoltaic panel is function to transform solar energy into electrical energy. Then the energy will be stored inside a battery so that the electrical energy supply will continue while at night. An electrical energy is saved at an enormous level by consuming the solar to power up the load

Int J Pow Elec \& Dri Syst, Vol. 11, No. 2, June 2020 : 651 - 657 
while solar charge controller function is to protect the charging battery against excess current. The floating material development in the other hand is more important in this project even it is not stated in the process of project because the photovoltaic panel will be placed at the floating material [8-13]. The project is depending on the strength of the floating material to withstand the solar panel to supply energy.

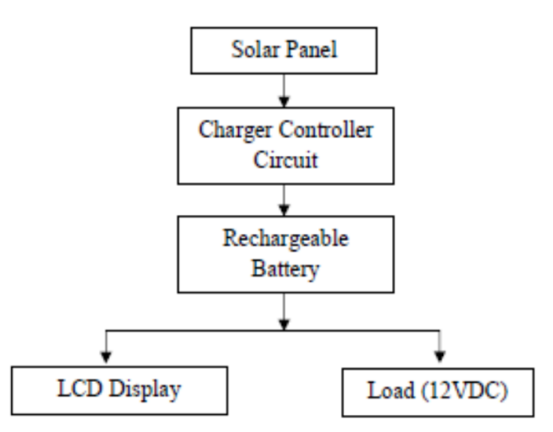

Figure 1. Block diagram of the project

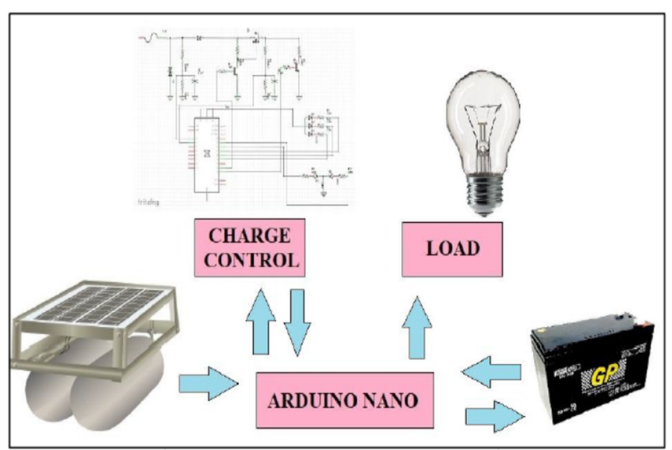

Figure 2. The complete circuit of the project

\subsection{Component of project}

This section discusses the main components in this research such as a solar module, a lead aced rechargeable battery, an arduino nano, an LCD display and a converter power module.

\subsubsection{Solar module}

The type of solar module is a polycrystalline, $12 \mathrm{~V}$ as a voltage output with a power rating of $10 \mathrm{~W}$. The solar panel a design with a frame in order to used for outdoor application. It is suitable designed for charging $12 \mathrm{~V}$ lead acid battery through solar charging controller. A Figure 3 shows the polycrystalline $12 \mathrm{~V}$ solar module and specification of solar panel as tabulated in Table 1 [14-18].

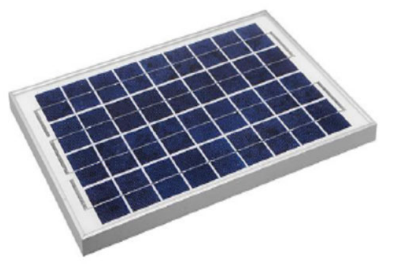

Table 1 The Specification of solar panel

\begin{tabular}{ccc}
\hline Variable & Type & polycrystalline $12 \mathrm{~V}$ solar module \\
\hline 1. & Rated & $10 \mathrm{~W}$, maximum output can \\
& & reach \\
2. & Efficiency of solar cell & $\sim 16.5 \%$ \\
3. & Dimension & $36 \mathrm{~cm} \mathrm{x} 24 \mathrm{~cm}$ \\
4. & Weight & 1.5 kilogram \\
5 & Thickness & $17 \mathrm{~mm}$ \\
\hline
\end{tabular}

Figure 3 . The polycrystalline $12 \mathrm{~V}$ solar module

\subsubsection{Lead acid rechargeable battery}

A $12 \mathrm{~V}$ rechargeable battery seal lead acid (SLA) as shown in Figure 4. The specification of a battery as tabulated in Table 2. The advantages of battery are robust, cheaper, and required a less of maintenance [20]. A DC power supply can be used to charge the battery as long as it delivers the accurate voltage amount to the battery. This battery use is capable for most of motors, $12 \mathrm{~V}$ controllers, or any other circuit or appliances [21]: 


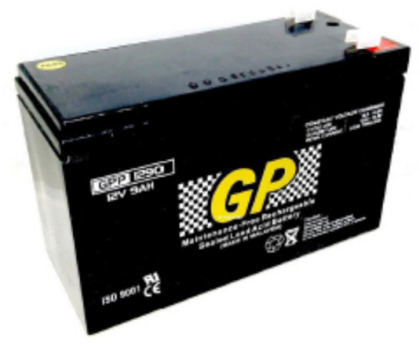

Table 2. Specification of $12 \mathrm{~V}$ lead acid rechargeable

\begin{tabular}{|c|c|c|}
\hline Variable & Item & Value \\
\hline 1. & Voltage & $12 \mathrm{~V}$ \\
\hline 2. & Capacity & $1.2 \mathrm{Ah}$ \\
\hline 3. & Size & $95 \mathrm{~mm} \times 42 \mathrm{~mm} \times 52 \mathrm{~mm}$ \\
\hline 4. & Origin & Malaysia \\
\hline 5. & Weight & $0.7 \mathrm{~kg}$ \\
\hline
\end{tabular}

Figure 4. 12V lead acid rechargeable battery

\subsubsection{Arduino Nano}

The Arduino Nano in this project is a compact, complete, small, and breadboard friendly board where constructed on the ATmega328P (Arduino Nano 3.x). It has relatively the similar functionality of Arduino Duemilanove, but in a dissimilar set. This Arduino Nano as a brain for this project because all the coding process for the project is uploads inside this small arduino nano. Figure 5 shows the Arduino Nano Board and the specification of the Arduino Nano as tabulated in Table 3 [22-25].

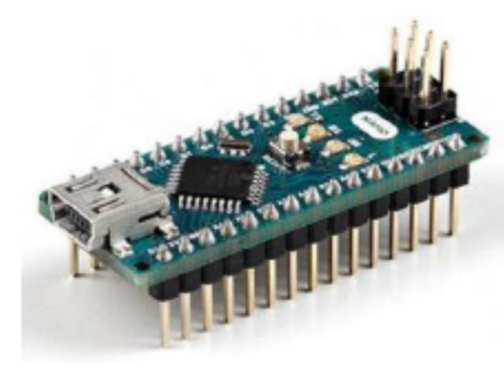

Figure 5. Arduino nano board
Table 3. Specification of the arduino nano

\begin{tabular}{|c|c|c|}
\hline Variable & Microcontroller & ATmega328 \\
\hline 1. & Architecture & AVR \\
\hline 2. & Operating Voltage & $5 \mathrm{~V}$ \\
\hline 3. & Flash Memory & $\begin{array}{c}32 \mathrm{~KB} \text { of which } \\
2 \mathrm{~KB} \text { used by } \\
\text { boot loader }\end{array}$ \\
\hline 4. & SRAM & $2 \mathrm{~KB}$ \\
\hline 5. & Clock Speed & $16 \mathrm{MHz}$ \\
\hline 6. & Analog IN Pins & 8 \\
\hline 7. & EEPROM & $1 \mathrm{~KB}$ \\
\hline 8. & DC Current per I/O & $\begin{array}{c}40 \mathrm{~mA}(\mathrm{I} / \mathrm{O} \\
\text { Pins) }\end{array}$ \\
\hline 9. & $\begin{array}{c}\text { Pins } \\
\text { Input Voltage }\end{array}$ & $\begin{array}{l}\text { Pins) } \\
7-12 V\end{array}$ \\
\hline 10. & Digital I/O Pins & $\begin{array}{c}22 \text { (6 of which } \\
\text { are PWM) }\end{array}$ \\
\hline 11. & PWM Output & 6 \\
\hline 12. & Power Consumption & $19 \mathrm{~mA}$ \\
\hline
\end{tabular}

\section{RESULTS AND ANALYSIS}

This section provides the details about the hardware and software results and analysis. It discusses the circuit design of the project.

\subsection{Prototype development}

This part discusses on the result of hardware testing for the solar charger controller circuit, the prototype structure and the complete circuit of the project.

\subsubsection{Solar charger controller monitoring circuit}

In this part, the solar charger controller circuit are testing on a breadboard before go to the soldering process. After all the connection in done, the coding is then being uploaded into the arduino nano board. A LED is used as an indicator for the circuit for charging condition with solar energy as a voltage supply. The I2C LCD 20x4 char is used to monitor the voltage from the solar panel, $\mathrm{V}_{\mathrm{S}}$ and from the battery, $\mathrm{V}_{\mathrm{B}}$, the temperature (Celsius), the charging indicator, Current (A), Power (W) and Energy (WH) of the project. An arduino nano, a current sensor and a temperature sensor using a $5 \mathrm{~V}$ as a voltage supply. A DC-DC Adjustable Step Down module are function to step down a $12 \mathrm{~V}$ to $5 \mathrm{~V}$ and as voltage supply to the three components as shown in Figure 6. Figure 7 shows the I2C display with symbols of solar panel (V), the battery symbols $(\mathrm{V})$, a current reading (A), and a power reading in watt (W). Next, there are three (3) sensors that are used to take reading for displaying it on the LCD that are a Voltage Sensor, Current Sensor and Temperature Sensor.

Int J Pow Elec \& Dri Syst, Vol. 11, No. 2, June 2020 : 651 - 657 


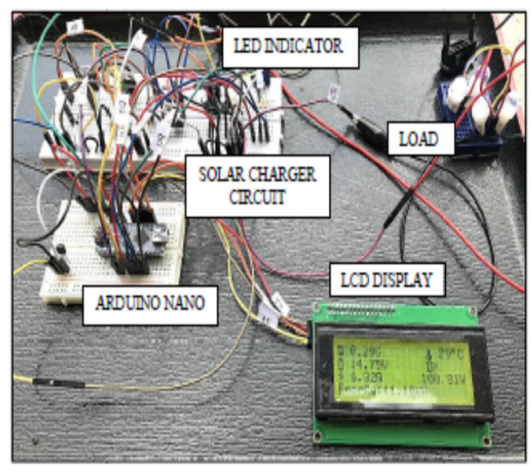

Figure 6. Circuit testing using a breadboard

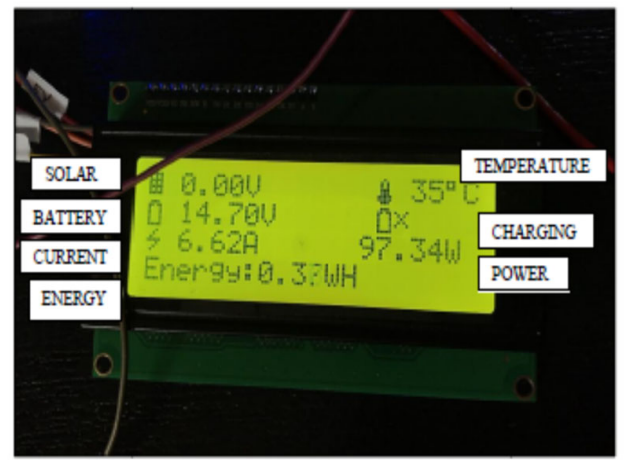

Figure 7. I2C LCD display output of project

Figure 8 shows indication of LED that will show the battery state of charge. It is important part to show the state of charge to describe the energy content inside a battery. A RGB LED is used to show the battery state of charge. Table 4 tabulated the state of charge in battery. For the load LED, A bi color (red/green) led is used for indication.

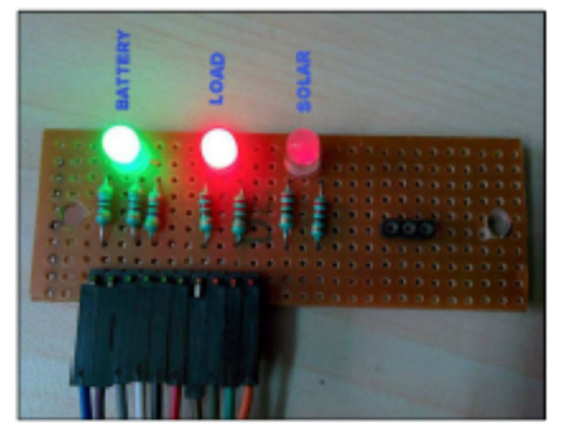

Table 4. Status of battery

\begin{tabular}{lll}
\hline LED Colour & Status of Battery & Voltage \\
\hline Red & Low & $<10.5 \mathrm{~V}$ \\
Green & Medium & $10.6 \mathrm{~V} \sim 13.5 \mathrm{~V}$ \\
Blue & Full & $13.6 \mathrm{~V}$ \\
\hline
\end{tabular}

Figure 8. Battery status using LED indicator

\subsubsection{Floating photovoltaic prototype development}

This part explains the result of prototype for the floating photovoltaic system. The prototype was tested to observe the performance of the floating solar material on water bodies and measure the power output from a solar panel. The setup of the overall configuration is shown in Figure 9 and 10.

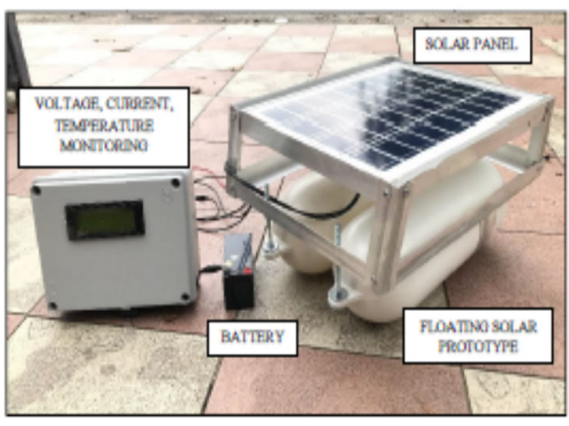

Figure 9. The setup of the overall project configuration

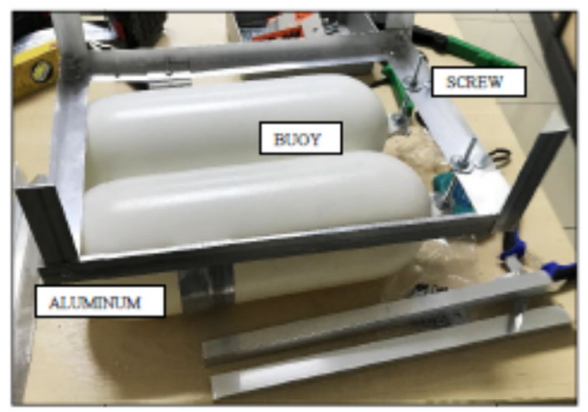

Figure 10. The body of floating solar panel 
Figure 10 shows the floating material for this project. A 2 nos of buoy is used for this floating solar project that been screw at the mounting structure. The material used for the mounting structure is aluminum. Aluminum is the best choice because it is lightweight and it can be used with contact with water without any rust. The prototype is floating at water bodies and also as a usual solar panel that are at land side shown in Figure 11 (a) and (b).

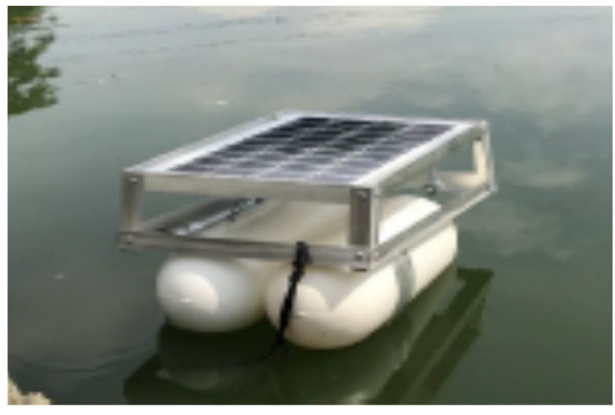

(a)

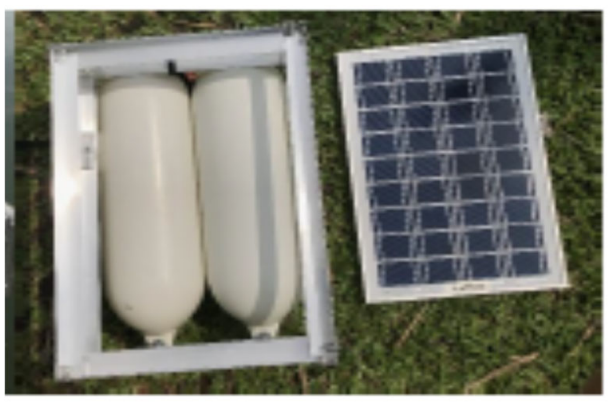

(b)

Figure 11. (a) The Prototype on water surface (b) The Prototype on the land

\subsubsection{Voltage, current and power output}

The value of voltage and current outputs has a measured at the G3 Pool, Universiti Tun Hussein Onn Malaysia, Johor, Malaysia area on $2^{\text {nd }}$ May 2019, $3^{\text {rd }}$ May 2019 and $4^{\text {th }}$ May 2019. An analysis in the decision taken in 8.00am until $6.00 \mathrm{pm}$, it's taken an hour once. The objective is to test the functionality of the system towards solar energy. At the same time, the voltage produced by the solar panel varied with respect to the intensity of solar radiation from the sun. The result can be seen in Figure 12 (a), (b) and (c). From the results shows that at 11.00 am until $1.00 \mathrm{pm}$ get the highest value of power with the fact the solar panel received maximum sunlight. The Figure 12(a) shown the performance of voltage versus time for three days: $2^{\text {nd }}, 3^{\text {rd }}$ and $4^{\text {th }}$ May 2019 . The maximum voltage is generating from $10.00 \mathrm{am}$ until $2.00 \mathrm{pm}$ for all the day. Next, the maximum of voltage is $19.30 \mathrm{~V}$ at $12.00 \mathrm{pm}, 2^{\text {nd }}$ May 2019 . The Figure 11(b) shows the performance of current versus time for the same day with Figure 12(a). The highest performance of currents is on $2^{\text {nd }}$ May 2019 with range value $0.2 \mathrm{~A}$ until $0.37 \mathrm{~A}$. Next, the maximum of current is $0.37 \mathrm{~A}, 12.00 \mathrm{pm}$ at the same day. The Figure 12(c) shows the performance of power versus time for three days are $2^{\text {nd }}$ May, $3^{\text {rd }}$ May and $4^{\text {th }}$ May 2019. The maximum power produce is $7.14 \mathrm{~W}$ at $2^{\text {nd }}$ May 2019.

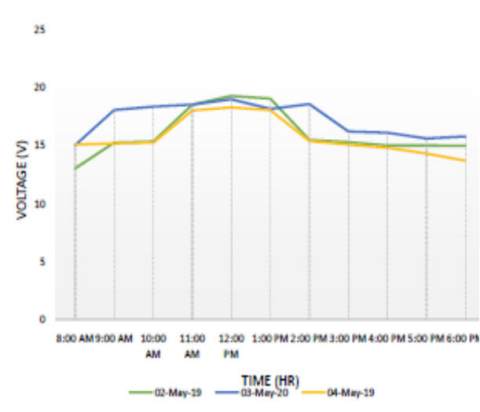

(a)

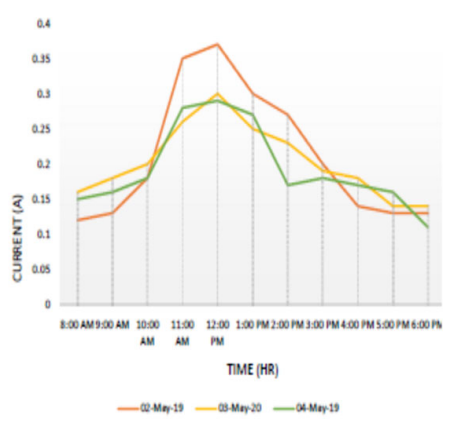

(b)

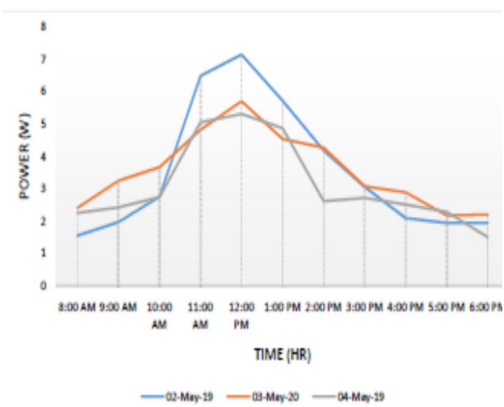

(c)

Figure 12 The Graph or (a) Voltage (b) Current (c) Power Output of three days measurement. 


\section{CONCLUSION}

A development of prototype the floating photovoltaic system has achieves all objectives. The system is using an ArduinoNano board to measure and display data output such as a voltage, acurrent, and a power. The first objective is to design and construct the prototype a floating photovoltaic to generate electricity. The system using an ArduinoNano board to measure and display data output such as a voltage, acurrent, and a power. The second objective is to test and evaluate the effectiveness of the floating photovoltaic on the water surface. Lastly, determine a performance of the voltage and current output of a floating system. The data is collected successfully and the LCD that displays the voltage is working nicely. The floating solar system as a alternative technique to made save land usage and it more safe to use because it does not have any pollution.

\section{REFERENCES}

[1] R. Cazzaniga, et al., "Compressed air energy storage integrated with floating photovoltaic plant," Journal of Energy Storage 13, pp. 48-57, 2017.

[2] Sun-Hee Kim, et al., "Application of Floating Photovoltaic Energy Generation Systems in South Korea", Hongik University, Korea, 17 Dec. 2016.

[3] Paritosh Sharma, et al., "Design Parameters of 10kW Floating Solar Power Plant," International Advanced Research Journal in Science, Engineering and Technology (IARJSET), vol 2, no. 1, May. 2015.

[4] Omkar D. Gaikwad and U. L. Deshpande, "evaporation Control Using Floating PV System and Canal Roof Top Solar System", International Advanced Research Journal in Science, Engineering and Technology (IARJSET), vol. 04, no. 4, Apr. 2017.

[5] Aseem Kumar Sharma and Prof. Dr. D P Kothari, "Uninterrupted Green Power using Floating Solar PV with pumped Hydro Energy Storage and Hydroelectric in India", vol. 3, no. 4, Sept 2016.

[6] Kleber Franke Portella, et al., "Feasibility and Environmental Sustainability of a $103.5 \mathrm{kWp}$ floating Photovoltaic Electrical System with a case study in a Hydroelectric Power Plant, Santa Clara Hpp, Located in the South of Brazil Region", International Journal of Advanced Engineering Research and Science, vol. 5, no. 6, Jun 2018.

[7] Divya Mittal, et al., "Floating Solar Photovoltaic System: An Overview and their Feasibility at Kota in Rajasthan", 2017 International Conference on Circuits Power and Computing Technologies.

[8] https://en.wikipedia.org/wiki/Floating_solar

[9] http://www.alternative-energy-news.info/floatingsolar-panels/

[10] Y. Choi, et al., "A Study on Major Design Elements of Tracking-Type Floating Photovoltaic Systems", Int. J. Smart Grid Clean Energy, vol. 3, no.1, pp. 70-74, Jul 2013

[11] Y. K. Choi and Y. G. Lee, "A Study on Development of Rotary Structure for Tracking-Type Floating Photovoltaic System." Int. J. Precis. Eng. Manuf, vol. 15, no. 11, pp. 2453-2460, Nov 2014.

[12] K. Trapani and D. L. Millar, "The Thin Film Flexible Floating PV (T3F-PV) Array: The Concept and Development of The Prototype", Renew. Energy, vol. 71, pp. 43-50, May 2014.

[13] K. Trapani and M. R. Santafe. "A Review of Floating Photovoltaic Installations: 2007-2013", Prog. Phtovolt: Res. Appl, pp. 1-9, Dec 2014.

[14] SolarLand 10W 12V Polycrystalline Solar Module Model: SLP010-12U, https://webosolar.com/store/en/12v-24vsolar-panels/902-solarland-10w-12v-polycrystalline-solar-module-slp010-12u.html.

[15] Heavy Duty Solar Panel, https:// tyconsystems.com/documentation / Spec\%20Sheets/ TPS\% 20Solar\% 20Panels $\% 20$ Spec\%20Sheet.pdf.

[16] Polycrystalline Solar Panels - YINGLI, https://www.selectsolar.co.uk/uploads/asset_file/yingli-data-sheet.pdf.

[17] Mohd Alif Saifuddin Jamalludin, et al., "Potential of floating solar technology in Malaysia", International Journal of Power Electronics and Drive System (IJPEDS), vol. 10, no. 3, pp. 1638-1644, 2019.

[18] M. Pushpavalli, N. M Jothi Swaroopan, "Performance analysis of hybrid photovoltaic/wind energy system using KY boost converter", International Journal of Power Electronics and Drive System (IJPEDS), vol. 10, no. 1, pp. 433-443, 2019.

[19] Monadhil Al-Chaderchi1, et al., "Enhancing the Performance of PV Panel Undergoing Shading Effects", International Journal of Power Electronics and Drive System (IJPEDS), vol. 9, no. 4, pp. 1937-1943, 2018.

[20] GP Back Up Battery 12V 1.2 AH Rechargeable PREMIUM Seal Lead Acid Battery for power back up, https:/gpback-up-battery-12v-12-ah-rechargeable-premium-seal-lead-acid-battery-for-power-back-up-i131277807s146339048.html?spm=a2o4k.searchlistbrand.list.16.3da0372fmZA1MP\&search=1.

[21] W. Abitha Memala, et al., "DC-DC Converter Based Power Management for Go Green Applications", International Journal of Power Electronics and Drive System (IJPEDS), vol. 10, no. 4, pp. 2046-2054, 2019.

[22] Arduino Nano (V2.3) User Manual, https://www.arduino.cc/en/uploads/Main/ArduinoNanoManual23.pdf

[23] Abdelkader Mezouari1, et al., "A New Photovoltaic Blocks Mutualization System for Micro-Grids Using an Arduino Board and Labview", International Journal of Power Electronics and Drive System (IJPEDS), vol. 9, no. 1, pp. 98-104, 2018.

[24] Siti Amely Jumaat, Mohammad Hilmi Othman, "Solar Energy Measurement Using Arduino", MATEC Web Conf. 150, 2018, 01007, pp. 6.

[25] Siti Amely Jumaat, et al., "Horizontal Single Axis Solar Tracker using Arduino Approach", Indonesian Journal of Electrical Engineering and Computer Science, vol. 12, no. 2, pp. 489-496, Nov 2018. 